\title{
F-AFLP GENOME SCAN AMONG FOURTEEN GENOTYPES OF SUNFLOWER (Helianthus annuus L.)
}

Rizk $^{1,2 *}$ M.S., Abd El-Twab ${ }^{1}$ F.M., Abo Doma ${ }^{1}$ A., Amar ${ }^{2}$ M.H. and Magdy ${ }^{1}$ M.

1- Genetics Dept., Fac. of Agric., Ain Shams Univ., P.O. Box 68, Hadayek Shobra 11241, Cairo, Egypt

2- Genetics Resource Dept., Desert Research Center, P.O. Box1, Mathaf El-Matariya St 11753 El-Matariya, Cairo, Egypt

*Corresponding author: drmokhtarsaid@yahoo.com

Received 6 June, 2018

Accepted 2 July, 2018

\section{ABSTRACT}

Sunflower (Helianthus annuus L.) belongs to the family Asteraceae. The current study used the fluorescent amplified fragment length polymorphism (F-AFLP) technique for evaluating the genetic diversity among 14 sunflower genotypes including eight agronomical traits. Highly significant difference between genotypes was observed for all studied traits $(p \leq 0.01)$. The results of correlation between the studied traits $(p \leq 0.05)$ revealed that positive correlations were observed between most of the traits. Six F-AFLP combination were succeeded in the development of 178 molecular markers within a total of 1007 polymorphic bands, with $97.42 \%$ polymorphic percentage. Concerning the molecular markers associated traits, 73 were observed related to morphological and yield component traits. These results may facilitate the simultaneous selection of several economic traits and can thus improve the efficacy of selection based on F-AFLP in the sunflower breeding programs.

Keywords: Sunflower, F-AFLP, Marker trait associations

\section{INTRODUCTION}

Sunflower (Helianthus annuus L.) is an important oil seed crop that belongs to family Asteraceae (Composite) originated in North America (Bukhsh et al 2011). The wild sunflowers from the genus Helianthus are branched annuals and perennials of family Asteraceae and is a diploid species $(2 n=2 x=34)$ (Aboki et al 2012). Globally, sunflower is one of the most important crop used for oil production allover the world. Seeds contain $40-50 \%$ oil and $23 \%$ protein and constitute an excellent source of unsaturated fats, crude protein, fibers and important nutrients like many vitamins such as ( $A, D$ and $E$ ) which support the immune system. Vitamin $A$ is antioxidant and prevents damage to body cells and organs and the appearance of premature aging. While, vitamin $D$ is needed for the growth of bones and teeth. However, vitamin $E$ is required to activate blood circulation (El-Wakil, 2014). In Egypt, sunflower represents the best choice for increasing local production of edible oils to overcome the shortage of its production (Kandil et al 2016). To overcome the problems associated with morphological traits, molecular genetic markers have many advantages over morphological traits including higher information content, which is of primary importance for systematization and registration of collection specimens (Mahmoud and Abdel-Fatah 2012). Molecular markers played a major role in identifying variation in genomic DNA sequences. Polymorphism at the molecular level in different crop species have contributed to assessment of genetic diversity, reconstruct accurate phylogenetic relationships and transferring of desired traits (Suresha et al 2017). The AFLP technique (Vos et al 1995) is widely used to characterise genetic diversity within and among populations, particularly in non-model organisms for which no prior DNA sequence information is available. Such wide multi-locus screening (also known as a genome scan) allows the identification of the so-called outlier loci for which alleles are highly differentiated among 
populations, and hence are potentially linked to adaptive divergence (Black et al 2001; Luikart et al 2003; Storz 2005 and Magdy et al 2016).

The overall aim of the present investigation was to assess the genetic diversity among fourteen genotypes of sunflower using some important morphological traits and F-AFLP molecular marker systems.

\section{MATERIALS AND METHODS}

Sunflower genotypes were obtained from different sources, their names and sources are presented in Table (1). Sunflower genotypes were evaluated at the molecular level using the fluorescence-based AFLP (F-AFLP) technique.

Table 1. Names of the fourteen sunflower genotypes and their sources

\begin{tabular}{|c|l|c|}
\hline Code No. & Common Name & Source \\
\hline S1 & Sakha53 & OCRD -FCRI-ARC \\
S2 & Qena & (NGB)- ARC \\
S3 & Al Buhayrah & (NGB)- ARC \\
S4 & The new Valley & (NGB)- ARC \\
S5 & The new Valley & (NGB)- ARC \\
S6 & Qena & (NGB)- ARC \\
S7 & Bani Sweif & (NGB)- ARC \\
S8 & Aswan & (NGB)- ARC \\
S9 & Sohag & (NGB)-ARC \\
S10 & Sohag & (NGB)-ARC \\
S11 & Luxor & (NGB)-ARC \\
S12 & Luxor & (NGB)-ARC \\
S13 & Luxor & (NGB)-ARC \\
S14 & Luxor & (NGB)- ARC \\
\hline
\end{tabular}

Sakha*53 Local variety, obtained from Oil Crops Research Department, Field Crops Res., Inst., Agricultural Res. Center, Giza, Egypt, while genotypes from S2 to S14 are accessions from the National Gene Bank, Agricultural Research Center, Giza, Egypt.

\section{Morphological traits}

A field experiment was conducted to evaluate fourteen sunflower genotypes for their morphological, yield and yield components traits. The studied yield related traits are: plant height $(\mathrm{cm})$, number of leaves, stem diameter $(\mathrm{cm})$, head diameter $(\mathrm{cm})$, head weight $(\mathrm{g})$, seeds weight $(\mathrm{g})$, number of seeds/head and 1000 seeds weight $(\mathrm{g})$.

\section{Statistical analysis}

The collected data were statistically analyzed using Costat program and correlations between eight yield related-traits were estimated. The differences among means were compared using Duncan's new multiple ranged test (Duncan 1955). The results were considered significant at $\mathrm{P}<0.01$.

\section{Genomic DNA Extraction}

Leaves samples of the fourteen sunflower genotypes were collected and were stored in liquid nitrogen for DNA extraction. Genomic DNA was extracted using Gene JET TM Plant Genomic DNA Purification Kit (Thermo Scientific, Lithuania).

\section{AFLP-polymerase chain reaction (PCR)}

The original protocol of Vos et al (1995) was followed using fluorescent primers instead of radioactive agents. All primers and adaptors were synthesized (Invitrogen, UK) and prepared as recommended (Table 2). Six different selective PCR combinations (3Eco $+\mathrm{NNN} \times 2 \mathrm{Mse}+\mathrm{NNN}$ primers) were amplified using the original PCR program.

Table 2. Sequence 5- 3'of primers and adaptors used to establish the AFLP-PCR technique

\begin{tabular}{|l|l|}
\hline Primer/ Adaptor & \multicolumn{1}{|c|}{ 5'sequence 3' } \\
\hline EcoRI - A1 & CTCGTAGACTGCGTACC \\
EcoRI - A2 & AATTGGTACGCAGTC \\
Mse I - A1 & GACGATGAGTCCTGAG \\
Mse I - A2 & TACTCAGGACTCAT \\
Eco + A & GACTGCGTACCAATTCA \\
Mse + C & GATGAGTCCTGAGTAAC \\
Eco + ACA & FAM-GACTGCGTACCAATTCACA \\
Eco + AGG & HEX-GACTGCGTACCAATTCAGG \\
Eco + ATA & CY3-GACTGCGTACCAATTCATA \\
Mse + CAA & GATGAGTCCTGAGTAACAA \\
Mse + CTC & GATGAGTCCTGAGTAACTC \\
\hline
\end{tabular}

\section{AFLP Analysis}

Automated AFLP scoring was performed using two programs Peak Scanner ${ }^{\mathrm{TM}}$ for peak calling and Raw Geno V2 for automated scoring, according to the software's manuals. The analysis of the AFLP data was based on the band-binary criterion (i.e. codifying the detected bands to, 1 when present and 0 when absent) and processed according to Bonin et al (2007). 


\section{Marker trait association analysis}

Marker trait association of the AFLP markers using 1000 seeds weight $(1000 \mathrm{~W})$, number of seeds per head (NSH), seeds weight (SW), head weight $(\mathrm{HW})$, stem diameter (SD), head diameter (HD), number of leaves (NL) and plant height $(\mathrm{PH})$ were analyzed by Power marker, using f-statistical analysis.

\section{RESULTS AND DISCUSSION}

Analyses of variance among the 14 sunflower genotypes were investigated to evaluate some important morphological traits. The results indicated that significant differences among studied genotypes were obtained. Significant differences were observed among all studied genotypes ( $p \leq 0.01$ ), as shown in Table (3).

Table 3. Mean values of some morphological traits for fourteen sunflower genotypes

\begin{tabular}{|c|c|c|c|c|c|c|c|c|c|}
\hline Genotypes & $\begin{array}{c}\text { Plant height } \\
\mathrm{Cm}\end{array}$ & $\begin{array}{l}\text { No. of } \\
\text { leaves }\end{array}$ & $\begin{array}{c}\text { Head } \\
\text { diameter } \\
\text { cm }\end{array}$ & $\begin{array}{c}\text { Stem } \\
\text { diameter } \\
\text { cm }\end{array}$ & $\begin{array}{c}\text { Head } \\
\text { weight } \\
\text { g. }\end{array}$ & $\begin{array}{c}\text { Seeds } \\
\text { weight } \\
\text { g. }\end{array}$ & $\begin{array}{c}\text { No. of } \\
\text { seeds } \\
\text { per head }\end{array}$ & $\begin{array}{c}1000 \\
\text { Seeds } \\
\text { weight } \\
\text { g. }\end{array}$ & $\mathbf{X}^{\prime \prime}$ \\
\hline S1 & $147.8^{\text {cdef }}$ & $25.8^{\mathrm{ab}}$ & $13.8^{\mathrm{ab}}$ & $5.6^{a b c}$ & $255.6^{a}$ & $116.7^{a}$ & $532.2^{a}$ & $220.3^{\mathrm{ab}}$ & 164.7 \\
\hline S2 & $141.9^{\text {ef }}$ & $23.8^{\mathrm{ab}}$ & $12.6^{\mathrm{ab}}$ & $5.8^{\mathrm{abc}}$ & $141.1^{\mathrm{abc}}$ & $60.6^{\mathrm{bcd}}$ & $401.7^{\mathrm{ab}}$ & $162.0^{\mathrm{abc}}$ & 118.7 \\
\hline S3 & $131.1^{\dagger}$ & $22.6^{\mathrm{ab}}$ & $8.9^{b}$ & $4.8^{\mathrm{abc}}$ & $58.3^{c}$ & $23.3^{d}$ & $270.3^{b}$ & $110.8^{a b c}$ & 78.8 \\
\hline S4 & $147.1^{\text {def }}$ & $26.3^{a}$ & $13.0^{\mathrm{ab}}$ & $5.8^{\mathrm{abc}}$ & $136.7^{\mathrm{abc}}$ & $71.1^{\mathrm{bc}}$ & $384.4^{\mathrm{ab}}$ & $190.4^{\mathrm{abc}}$ & 121.9 \\
\hline S5 & $155.2^{\text {bcdef }}$ & $22.8^{\mathrm{ab}}$ & $14.8^{a}$ & $6.6^{a}$ & $158.3^{a b c}$ & $57.2^{\mathrm{bcd}}$ & $440.6^{a b}$ & $128.7^{\mathrm{abc}}$ & 123.0 \\
\hline S6 & $176.1^{\mathrm{abcd}}$ & $19.4^{\mathrm{bc}}$ & $12.8^{\mathrm{ab}}$ & $5.7^{\mathrm{abc}}$ & $145.6^{\mathrm{abc}}$ & $42.2^{\mathrm{bcd}}$ & $352.0^{\mathrm{ab}}$ & $131.5^{\mathrm{abc}}$ & 110.7 \\
\hline S7 & $180.1^{a b}$ & $20.8^{a b c}$ & $14.9^{a}$ & $6.4^{\mathrm{ab}}$ & $187.8^{a b}$ & $56.7^{\mathrm{bcd}}$ & $520.0^{a}$ & $104.6^{b c}$ & 136.4 \\
\hline S8 & $193.3^{\mathrm{a}}$ & $25.2^{\mathrm{ab}}$ & $12.6^{\mathrm{ab}}$ & $5.6^{\mathrm{abc}}$ & $172.2^{\mathrm{abc}}$ & $74.4^{\mathrm{bc}}$ & $344.9^{b}$ & $267.6^{\mathrm{ab}}$ & 137.0 \\
\hline s9 & $152.8^{\text {bcdef }}$ & $21.8^{\mathrm{abc}}$ & $9.6^{a b}$ & $4.7^{\mathrm{bc}}$ & $113.9^{b c}$ & $33.9^{c d}$ & $271.7^{b}$ & $142.6^{a b c}$ & 93.9 \\
\hline S10 & $165.7^{\text {abcde }}$ & $15.1^{\mathrm{c}}$ & $14.0^{\mathrm{ab}}$ & $4.6^{c}$ & $211.1^{\mathrm{ab}}$ & $77.2^{a b}$ & $313.9^{a b}$ & $241.8^{a}$ & 130.4 \\
\hline S11 & $178.3^{\mathrm{abc}}$ & $26.6^{a}$ & $11.0^{\mathrm{ab}}$ & $5.1^{\mathrm{abc}}$ & $114.4^{\mathrm{bc}}$ & $36.7^{\mathrm{bcd}}$ & $440.0^{\mathrm{ab}}$ & $82.9^{c}$ & 111.9 \\
\hline S12 & $156.1^{\text {bcdef }}$ & $19.3^{\mathrm{bc}}$ & $13.4^{\mathrm{ab}}$ & $4.7^{\mathrm{bc}}$ & $144.4^{\mathrm{abc}}$ & $35.6^{\mathrm{cd}}$ & $396.7^{\mathrm{ab}}$ & $103.0^{b c}$ & 109.2 \\
\hline $\mathrm{s} 13$ & $155.6^{\text {bcdef }}$ & $20.3^{a b c}$ & $13.2^{\mathrm{ab}}$ & $5.1^{a b c}$ & $238.9^{a b}$ & $62.8^{\mathrm{bcd}}$ & $364.1^{\mathrm{ab}}$ & $233.3^{a b}$ & 136.7 \\
\hline S14 & $147.8^{\text {cdef }}$ & $24.7^{\mathrm{ab}}$ & $10.4^{\mathrm{ab}}$ & $4.7^{\mathrm{bc}}$ & $134.4^{\mathrm{abc}}$ & $39.4^{\mathrm{bcd}}$ & $375.9^{\mathrm{ab}}$ & $101.4^{b c}$ & 104.8 \\
\hline$x$ & 159.2 & 22.5 & 12.5 & 5.4 & 158.1 & 56.3 & 386.3 & 158.6 & 159.2 \\
\hline LSD 0.01 & 30.99 & 6.72 & 5.7 & 1.9 & 125.3 & 41.0 & 235.1 & 134.6 & \\
\hline
\end{tabular}

Means followed by the same letter (s) are not significantly different by Duncan`s new multiple range test at $(p \leq 0.01)$.

Genotype S8 recorded the highest plant height $(193.3 \mathrm{~cm})$, whereas genotype $S_{3}$ revealed the lowest one $(131.1 \mathrm{~cm})$. Two genotypes $S_{1}$ and $S_{8}$ recorded the highest values of number of leaves/plant 25.8 and 25.2, respectively, whereas only one genotype $S_{10}$ revealed the lowest number of leaves/plant value (15.1). While, genotype $S_{7}$ showed the highest head diameter/plant value $(14.9 \mathrm{~cm}), \mathrm{S}_{3}$ recorded the lowest head diameter values: $8.9 \mathrm{~cm}$. Regarding to the stem diameter at harvest, genotype S7 displayed the highest diameter value $(6.4 \mathrm{~cm})$, meanwhile the three genotypes: $S_{9}, S_{12}$ and $S_{14}$ exhibited the lowest diameter value
$(4.7 \mathrm{~cm})$. With respect to the head weight/plant, there were wide differences within the 14 sunflower genotypes, it was $58.3 \mathrm{~g}$ in $\mathrm{S}_{3}$ genotype and reached $255.6 \mathrm{~g}$ in $S_{1}$ genotype, respectively. $S_{1}$ genotype recorded the highest number of seeds/head value (532.2), meanwhile, the two genotypes $S_{3}$ and $S_{9}$ recorded the lowest value in this respect with mean of 270.3 and 271.7 , respectively. The results of seeds weight/plant varied from $23.3 \mathrm{~g}$ in $\mathrm{S} 3$ genotype to $116.7 \mathrm{~g}$ in $\mathrm{S}_{1}$ genotype, respectively. In the context, the seed index (weight of 1000 seeds/plant) were recorded among the studied genotypes and the results showed sig- 
nificant differences varied from $82.9 \mathrm{~g}$ in $\mathrm{S}_{11}$ genotype to $267.6 \mathrm{~g}$ in $\mathrm{S} 8$ genotype, respectively. Our results were in agreement with those reported by (Razzaq et al 2014) who evaluated ten sunflower genotypes using the morphological traits and genetic variability. However, (Purwati and Herwati 2016) estimated low variation values in some quantitative traits and the qualitative traits. Overall, the results indicated that some traits could be used as selection criteria in sunflower breeding programs for appropriate screening of parental genotypes included in hybridizing process aiming at increasing plant productivity. More recently, (Riaz et al 2017) studied the seed yield and related components in sunflower using diallel crossing. The results were recorded on quantitative traits analysis of variance and combining abilities, and indicated that the genotypes were significant in general combining ability effects for days to maturity, plant height, stem diameter, head diameter, number of leaves, filled seed, seed per head and seed yield per plant.

\section{Correlation among yields-related traits}

Correlations between eight yields-related traits were evaluated among 14 genotypes of sunflower
(Table 4). The results indicated positive correlations between head diameter and the four traits including: stem diameter, head weight, seeds weight and number of seeds per head, which recorded $0.6147,0.7247,0.6025$ and 0.5453 , respectively. Additionally, a significant correlation was observed between head weight and both of seeds weight (0.8177) and 1000 seeds weight (0.6816). However, seed weight/plant recorded highly significant and positive correlation with 1000 seeds weight $(0.7640)$. The results of correlation between the yield-related traits of sunflower were in agreement with (Purwati and Herwati 2016) who examined three genotypes of sunflower and found that seed size and seed thickness showed significant positive correlation with100 seeds weight. More recently, (Chambó et al 2017) served eight sunflower genotypes to estimate the correlation values for nine agronomic traits. In both tests, there were significant $(p<0.05)$ positive correlation values between seed yield \& head diameter, head diameter, both of number and diameter of seeds per head and first and last count of germination. The path analysis, in both pollination tests, indicated that head diameter had the highest direct effect on seed yield.

Table 4. Correlation between the eight yields-related traits of sunflower

\begin{tabular}{|l|c|c|c|c|c|c|c|}
\hline \multicolumn{1}{|c|}{ Traits } & $\begin{array}{c}\text { Plant } \\
\text { height } \\
\text { cm }\end{array}$ & $\begin{array}{c}\text { No. of } \\
\text { leaves }\end{array}$ & $\begin{array}{c}\text { Head } \\
\text { diameter } \\
\text { cm }\end{array}$ & $\begin{array}{c}\text { Stem } \\
\text { diameter } \\
\text { cm }\end{array}$ & $\begin{array}{c}\text { Head } \\
\text { weight } \\
\mathbf{g .}\end{array}$ & $\begin{array}{c}\text { Seeds } \\
\text { weight } \\
\mathbf{g .}\end{array}$ & $\begin{array}{c}\text { No. of } \\
\text { seeds } \\
\text { per head }\end{array}$ \\
\hline No. of Leaves & -0.1042 & $\mathbf{1}$ & & & & & \\
Head diameter cm & 0.3487 & -0.2833 & $\mathbf{1}$ & & & & \\
Stem diameter cm & 0.2508 & 0.2672 & $\mathbf{0 . 6 1 4 7 ^ { * }}$ & $\mathbf{1}$ & & & \\
Head weight g. & 0.2513 & -0.2191 & $\mathbf{0 . 7 2 4 7 ^ { * }}$ & 0.2161 & $\mathbf{1}$ & & \\
Seeds weight g. & 0.0933 & 0.1443 & $\mathbf{0 . 6 0 2 5 ^ { \star }}$ & 0.3263 & $\mathbf{0 . 8 1 7 7 ^ { * }}$ & $\mathbf{1}$ & \\
No. of seeds per head & -0.0495 & 0.1912 & $\mathbf{0 . 5 4 5 3 ^ { * }}$ & 0.5084 & 0.4029 & 0.3505 & $\mathbf{1}$ \\
1000 seeds weight g. & 0.0802 & -0.1322 & 0.3409 & -0.0254 & $\mathbf{0 . 6 8 1 6 ^ { * }}$ & $\mathbf{0 . 7 6 4 0 ^ { * }}$ & -0.2477 \\
\hline
\end{tabular}

${ }^{*}=$ Correlation significant test at $(p \leq 0.05)$

\section{AFLP genomes scan}

Six primers combination of F-AFLP were used to identify the genetic diversity among 14 genotypes of sunflower. In general, the total positive unique markers recorded 178 positive markers which ranged in size from 50 to $659 \mathrm{bp}$, as presented in Table (5) and Figures (1, 2 and 3). A total positive unique marker were exhibited by $\mathrm{C} 1$ Blue combination Figure (1) and Table (5) which recorded (34) markers ranged from 90 to 526 bp in size. $\mathrm{S}_{13}$ genotype scored the highest positive unique marker (28) and recorded the highest four molecular size 526,446,435 and 434 bp. However, $\mathrm{S}_{8}$ and $\mathrm{S}_{12}$ genotypes showed the lowest molecular size (90 and $95 \mathrm{bp}$ ), respectively. 
Table 5. Summary of positive unique F-AFLP markers via fourteen sunflower genotypes across the C1 and C4 Blue primers combination

\begin{tabular}{|c|c|c|c|c|c|c|c|}
\hline \multirow[b]{2}{*}{ Genotype } & \multicolumn{6}{|c|}{ Unique positive markers } & \multirow[b]{2}{*}{$\begin{array}{c}\text { Total } \\
\text { grand } \\
\text { markers }\end{array}$} \\
\hline & $\begin{array}{c}\text { Combinations } \\
\text { name }\end{array}$ & $\begin{array}{l}\text { Amplicon } \\
\text { size (bp) }\end{array}$ & \begin{tabular}{|c|}
$\begin{array}{c}\text { Total } \\
\text { number of } \\
\text { markers }\end{array}$ \\
\end{tabular} & $\begin{array}{c}\text { Combinations } \\
\text { name }\end{array}$ & $\begin{array}{l}\text { Amplicon size } \\
\text { (bp) }\end{array}$ & \begin{tabular}{|c|} 
Total \\
number of \\
markers
\end{tabular} & \\
\hline S1 & \multirow{14}{*}{ C1-Blue } & 113 & 1 & \multirow{14}{*}{ C4-Blue } & 122 & 1 & 2 \\
\hline S2 & & - & - & & 77 & 1 & 1 \\
\hline S3 & & 122 & 1 & & - & - & 1 \\
\hline S4 & & - & - & & $376,151,61$ & 3 & 3 \\
\hline S5 & & 161 & 1 & & - & - & 1 \\
\hline S6 & & 415 & 1 & & 242 & 1 & 2 \\
\hline S7 & & - & - & & 111,61 & 2 & 2 \\
\hline S8 & & 90 & 1 & & - & - & 1 \\
\hline s9 & & - & - & & - & - & - \\
\hline S10 & & - & - & & - & - & - \\
\hline S11 & & - & - & & 125 & 1 & 1 \\
\hline $\mathrm{S} 12$ & & 95 & 1 & & - & - & 1 \\
\hline S13 & & $\begin{array}{c}526,446,435,434, \\
383,345,343,310, \\
304,299,280,265, \\
256,255,242,240, \\
228,221,218,215, \\
209,194,174,167, \\
164,152,150,118\end{array}$ & 28 & & $\begin{array}{c}440,410,401 \\
362,343,338 \\
284,239,210 \\
187,185,168 \\
89\end{array}$ & 13 & 41 \\
\hline $\mathrm{S} 14$ & & - & - & & $\begin{array}{c}494,472,236 \\
186,74\end{array}$ & 5 & 5 \\
\hline Total & & & 34 & & & 27 & 61 \\
\hline
\end{tabular}

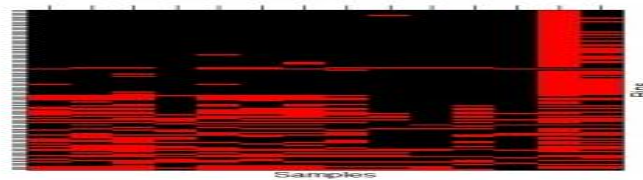

C1-Bime

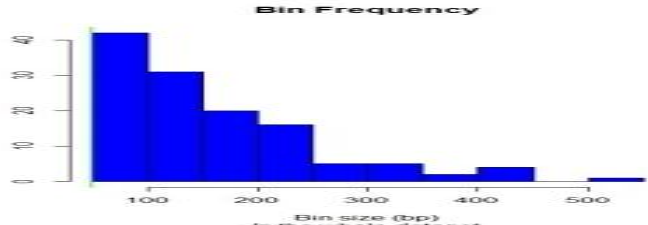

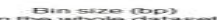

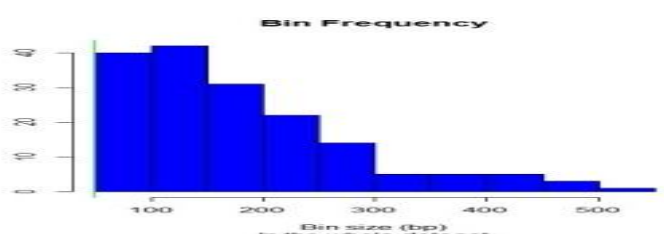

Fig. 1. F-AFLP profiles of 14 sunflower genotypes using two pairs of primers combination C1 and C4 Blue, where Sakha53, Qena (S1), Al-Buhayrah (S2), New Valley (S3-S4), Qena (S5), Bani Sweif (S6), Aswan (S7), Sohag (S8-S9) and Luxor (S10-S14). 


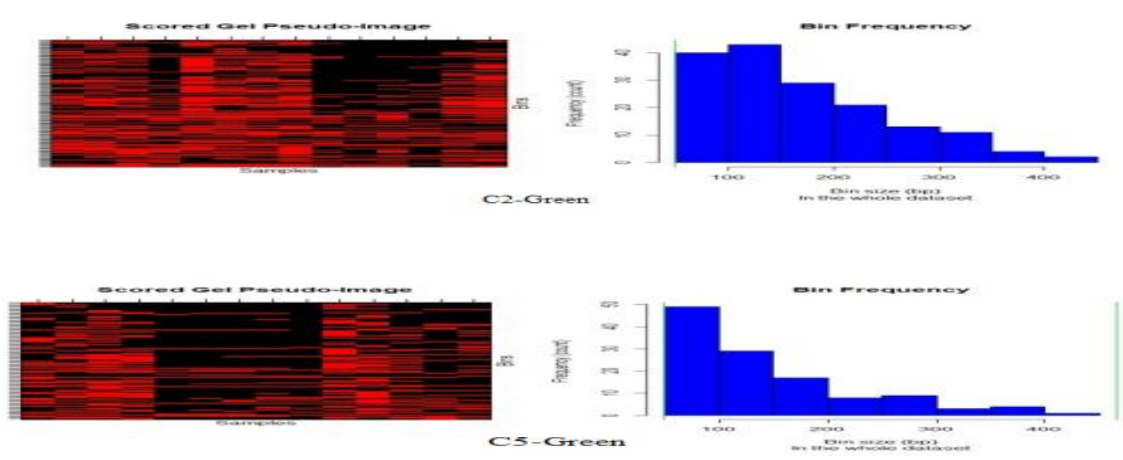

Fig. 2. F-AFLP profiles of 14 sunflower genotypes using two pair of primers combination C2and C5-Green, where Sakha53, Qena (S1), Al-Buhayrah (S2), New Valley (S3-S4), Qena (S5), Bani Sweif (S6), Aswan (S7), Sohag (S8-S9) and Luxor (S10-S14).
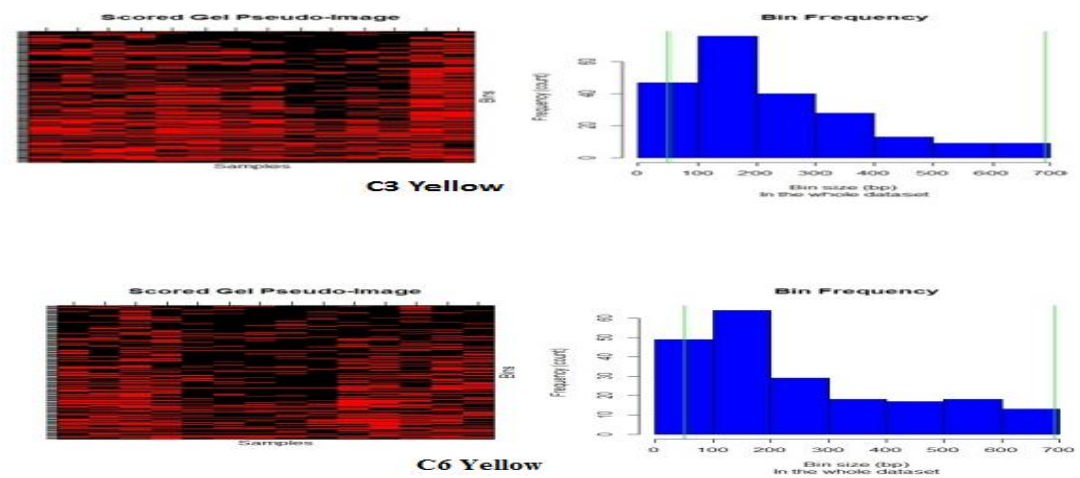

Fig. 3. F-AFLP profiles of 14 sunflower genotypes using two pair of primers combination C3and C6-Yellow where Sakha53, Qena (S1), Al-Buhayrah (S2), New Valley (S3-S4), Qena (S5), Bani Sweif (S6), Aswan (S7), Sohag (S8-S9) and Luxor (S10-S14).

For the C4- Blue combination, 27 positive unique marker were recorded and ranged from 61 to $494 \mathrm{bp}$ in size. $\mathrm{S}_{13}$ genotype scored the highest positive unique marker (13), meanwhile, $\mathrm{S}_{14}$ genotype counted the highest two molecular size 494 and $472 \mathrm{bp}$. On the other hand, $\mathrm{S}_{4}, \mathrm{~S}_{7}, \mathrm{~S}_{14}$ and $\mathrm{S}_{2}$ genotypes exhibited the lowest molecular size $(61$, 61, 74 and 77 bp), respectively. In C2- Green combination, 19 positive unique marker were recorded and ranged from 56 to $400 \mathrm{bp}$ in size as shown in Figure (2) and Table (6). $S_{2}$ genotype scored the highest positive unique marker (4), while, $\mathrm{S}_{14}, \mathrm{~S}_{10}, \mathrm{~S}_{2}$ and $\mathrm{S}_{11}$ genotypes counted the highest four molecular size $(400,339,334$ and 328 bp) respectively. However, $S_{11}, S_{12}, S_{13}$ and $S_{14}$ genotypes recorded the lowest molecular size: 56 , 56,83 and $95 \mathrm{bp}$, respectively. The results of C5Green combination, exhibited a total of positive unique marker (23) ranged from 78 to $431 \mathrm{bp}$ in size, as shown in Figure (2) and Table (6). $S_{7}$ and $S_{11}$ genotypes recorded the highest number of positive unique marker ( 6 and 5 ), however $S_{1}$ genotype counted the two highest molecular size 431 and 385 , as well as, $S_{7}$ and $S_{10}$ recorded the highest molecular size 382 and $377 \mathrm{bp} . \mathrm{S}_{9}, \mathrm{~S}_{11}, \mathrm{~S}_{1}$ and $\mathrm{S}_{2}$ genotypes presented the lowest molecular size 78, 80, 93 and 98bp, respectively. In the same context, C3- Yellow combinations, 31 positive unique marker were recorded and ranged from 50 to 659 bp in size as shown in Figure (3) and Table (7). S13 and S12 genotypes scored the highest positive unique marker (7 and 6), while, five genotypes presented only one positive unique marker (S1, S3, S7, S8 and S10), respectively. S9, S12 and $\mathrm{S} 13$ genotypes counted the highest three molecular sizes 659, 579 and 567bp, respectively. 
(Helianthus annuus L.)

While, S11 recorded the three highest positive unique marker (539,448 and $411 \mathrm{bp})$, respectively. However, S1, S14, S13, S12, S3 and S2 genotypes exhibited the lowest molecular size ranged from 50 to $95 \mathrm{bp}$, respectively. Whereas, three genotypes were failed to record any positive unique marker (S4, S5 and S6), respectively.

Table 6. Summary of positive unique F-AFLP markers via fourteen sunflower genotypes across the C2 and C5- Green primers combination

\begin{tabular}{|c|c|c|c|c|c|c|c|}
\hline \multirow[b]{2}{*}{ Genotype } & \multicolumn{6}{|c|}{ Unique positive markers } & \multirow[b]{2}{*}{$\begin{array}{c}\text { Total } \\
\text { grand } \\
\text { markers }\end{array}$} \\
\hline & $\begin{array}{c}\text { Combinations } \\
\text { name }\end{array}$ & $\begin{array}{c}\text { Amplicon } \\
\text { size (bp) }\end{array}$ & $\begin{array}{c}\text { Total } \\
\text { number of } \\
\text { markers }\end{array}$ & $\begin{array}{c}\text { Combinations } \\
\text { name }\end{array}$ & $\begin{array}{l}\text { Amplicon } \\
\text { size (bp) }\end{array}$ & $\begin{array}{c}\text { Total } \\
\text { number of } \\
\text { markers }\end{array}$ & \\
\hline S1 & \multirow{14}{*}{ C2-Green } & 220 & 1 & \multirow{14}{*}{ C5-Green } & $\begin{array}{c}431,385,154 \\
93\end{array}$ & 4 & 5 \\
\hline S2 & & $\begin{array}{c}334,185,13 \\
8,137\end{array}$ & 4 & & 267,98 & 2 & 6 \\
\hline S3 & & 216 & 1 & & - & - & 1 \\
\hline S4 & & - & - & & - & - & - \\
\hline S5 & & - & - & & - & - & - \\
\hline S6 & & - & - & & - & - & - \\
\hline S7 & & - & - & & $\begin{array}{c}382,314,227 \\
226,176,105\end{array}$ & 6 & 6 \\
\hline S8 & & - & - & & $263,201,89$ & 3 & 3 \\
\hline S9 & & 116 & 1 & & 78 & 1 & 2 \\
\hline $\mathrm{S} 10$ & & 339 & 1 & & 377 & 1 & 2 \\
\hline $\mathrm{S} 11$ & & $328,319,56$ & 3 & & $\begin{array}{c}294,290,125 \\
104,80\end{array}$ & 5 & 8 \\
\hline $\mathrm{S} 12$ & & $120,117,56$ & 3 & & 163 & 1 & 4 \\
\hline $\mathrm{S} 13$ & & 218,83 & 2 & & - & - & 2 \\
\hline $\mathrm{S} 14$ & & $400,285,95$ & 3 & & 149 & 1 & 4 \\
\hline Total & & & 19 & & & 23 & 43 \\
\hline
\end{tabular}


Table 7. Summary of positive unique F-AFLP markers via fourteen sunflower genotypes across the C3 and C6- yellow primers combination

\begin{tabular}{|c|c|c|c|c|c|c|c|}
\hline \multirow[b]{2}{*}{ Genotype } & \multicolumn{6}{|c|}{ Unique positive markers } & \multirow[b]{2}{*}{$\begin{array}{c}\text { Total } \\
\text { grand } \\
\text { markers }\end{array}$} \\
\hline & $\begin{array}{c}\text { Combinations } \\
\text { name }\end{array}$ & $\begin{array}{l}\text { Amplicon } \\
\text { size (bp) }\end{array}$ & $\begin{array}{c}\text { Total } \\
\text { number of } \\
\text { markers }\end{array}$ & $\begin{array}{c}\text { Combinations } \\
\text { name }\end{array}$ & $\begin{array}{l}\text { Amplicon } \\
\text { size+ (bp) }\end{array}$ & $\begin{array}{c}\text { Total } \\
\text { number of } \\
\text { markers }\end{array}$ & \\
\hline S1 & & 50 & 1 & & $281,252,140$ & 3 & 4 \\
\hline S2 & & $\begin{array}{c}301,273 \\
95\end{array}$ & 3 & & 628,598 & 2 & 5 \\
\hline S3 & & 92 & 1 & & - & - & 1 \\
\hline S4 & & - & - & & - & - & - \\
\hline S5 & & - & - & & 563,502 & 2 & 2 \\
\hline S6 & & - & - & & 595,484 & 2 & 2 \\
\hline S7 & & 297 & 1 & & 119,98 & 2 & 3 \\
\hline S8 & & 388 & 1 & & $128,89,57$ & 3 & 4 \\
\hline S9 & & 659,189 & 2 & & $565,540,214$ & 3 & 5 \\
\hline S10 & & 156 & 1 & & $594,483,468$ & 3 & 4 \\
\hline S11 & C3-yellow & $\begin{array}{l}539,448 \\
411,305\end{array}$ & 4 & C6-yellow & $\begin{array}{c}596,589,574, \\
534,477,350, \\
260,211,126\end{array}$ & 9 & 13 \\
\hline S12 & & $\begin{array}{c}579,182,120 \\
102,99,56\end{array}$ & 6 & & $\begin{array}{c}641,569,453, \\
352,246,162, \\
127\end{array}$ & 7 & 13 \\
\hline $\mathrm{S} 13$ & & $\begin{array}{c}567,356,264 \\
246,134,83,66\end{array}$ & 7 & & 133 & 1 & 8 \\
\hline S14 & & $479,224,95,53$ & 4 & & $\begin{array}{c}267,249,232 \\
143,119,84 \\
\end{array}$ & 6 & 10 \\
\hline Total & & & 31 & & & 43 & 74 \\
\hline
\end{tabular}

For the last combination (C6- Yellow), a total of 43 positive unique marker were observed ranging in size from 57 to $641 \mathrm{bp}$. $\mathrm{S}_{11}, \mathrm{~S}_{12}$ and $\mathrm{S}_{14}$ genotypes recorded the highest positive unique marker (9, 7 and 6), respectively, while, $S_{13}$ showed only one positive unique marker. $\mathrm{S}_{2}, \mathrm{~S}_{5}, \mathrm{~S}_{6}, \mathrm{~S}_{9}, \mathrm{~S}_{10}, \mathrm{~S}_{11}$ and $S_{12}$ genotypes exhibited the highest three molecular size ranging from (641 to $453 \mathrm{bp}$ ), in contrast, $\mathrm{S}_{6}$ and $\mathrm{S}_{14}$ genotypes recorded the lowest molecular size being 57 and 84 bp. Two genotypes, $S_{3}$ and $S_{4}$ did not show any positive unique marker. In summary, the total positive unique marker for each two pairs of primer combination $\mathrm{C}_{1}$ \& $\mathrm{C}_{4}$-Blue, $\mathrm{C}_{2} \& \mathrm{C}_{5}$ green and $\mathrm{C}_{3} \& \mathrm{C}_{6}$ yellow exhibits (61), (43) and (74) markers, respectively. The results of F-AFLP in sunflower agreed with Gonthier et al (2013) who constructed the highdensity genetic maps between two plants, K28 (male-sterile) and $\mathrm{K} 59$ (pollen-fertile), at the Slocus. Bulks and parental plants K28 and K59 were screened using AFLP analysis, with a complete set of 256 primer combinations of EcoRI-ANN and Msel-CNN. Thirteen AFLP markers were identified close to the NMS1-locus and six in the vicinity of the S-locus. The results suggested that a total of 31,000 fragments were generated, of which 2,350 showed polymorphism between $\mathrm{K} 59$ and K28. Additionally, Reif et al (2013) evaluated 133 intragroup and 104 intergroup hybrids with their parental lines in sunflower. The results showed that there was a total of 572 AFLP markers across the parental lines. Moreover, Zhang et al (2014) studied two sunflower varieties using SSR and AFLP. The results indicated that a total of 84 and 108 polymorphic bands were recorded for SSR and AFLP, respectively. 


\section{Discrimination capacity of F-AFLP}

For the estimation of the discrimination capacity of F-AFLP, several parameters were evaluated as shown in Table (8). The percentages of polymorphic amplicons were $97.42 \%$ with a total of 1007 amplicons. While the total number of polymorphic amplicons (PA) was 981 amplicons ranged from 119 within the combination C5-green to 208 amplicons in C3-yellow combination. Combination C3-yellow showed the highest number of amplicons (222), whereas combination C5-green showed the lowest number of amplicons (120). The highest percentage of polymorphic was obtained within the combination C1-bule with $100 \%$, while the lowest PA\% was revealed within the combination C3- yellow being $93.69 \%$.

Table 8. Summary of the polymorphic, monomorphic amplicons, \% of polymorphic and positive unique marker monomorphic amplicons by six F-AFLP combinations

\begin{tabular}{|c|c|c|c|c|c|c|}
\hline $\begin{array}{c}\text { Combination } \\
\text { name }\end{array}$ & $\begin{array}{c}\text { Monomorphic } \\
\text { amplicons } \\
\text { (MA) }\end{array}$ & $\begin{array}{c}\text { Polymorphic } \\
\text { amplicons } \\
\text { (PA) }\end{array}$ & $\begin{array}{c}\text { Total } \\
\text { number of } \\
\text { amplicons }\end{array}$ & $\begin{array}{c}\text { Percentage of } \\
\text { monomorphic } \\
\text { amplicons }\end{array}$ & $\begin{array}{c}\text { Percentage of } \\
\text { polymorphism }\end{array}$ & $\begin{array}{c}\text { Total of } \\
\text { positive } \\
\text { unique } \\
\text { marker }\end{array}$ \\
\hline C6-yellow & 1 & 207 & 208 & $0.48 \%$ & $99.52 \%$ & 43 \\
C3-yellow & 14 & 208 & 222 & $6.31 \%$ & $93.69 \%$ & 31 \\
C2-Green & 8 & 155 & 163 & $4.91 \%$ & $95.09 \%$ & 19 \\
C4-blue & 2 & 166 & 168 & $1.19 \%$ & $98.81 \%$ & 27 \\
C1-Blue & 0 & 126 & 126 & $0.00 \%$ & $100.00 \%$ & 34 \\
C5-green & 1 & 119 & 120 & $0.83 \%$ & $99.17 \%$ & 23 \\
\hline Total & 26 & 981 & 1007 & $2.58 \%$ & $97.42 \%$ & 178 \\
\hline
\end{tabular}

In this regards, our results were in partial agreement with those of Gonthier et al (2013) who used AFLP analysis with a complete set of 256 primer combinations. A total of 31,000 fragments were generated, of which 2,350 showed polymorphism. Moreover, Zhang et al (2014) reported that a total 1460 bands were detected by AFLP analysis using 48 of AFLP primer combinations among some sunflower genotypes. The total number of PA detected by AFLP analysis was 1119 bands $(60.48 \%)$, while 557 bands were polymorphic with the percentage of PA $39.52 \%$.
Marker traits association in sunflower genotypes

With regard to the total positive unique marker which were counted 73 positive markers ranged from 52 to $682 \mathrm{bp}$ in size, while the $\mathrm{P}$-value thresholds for the association between F-AFLP markers and the different measured sunflower traits ranged from 2 to 3.66 under ( $p \leq 0.01)$, and their densitometric analysis as shown in Table (9). 


\begin{tabular}{|c|c|c|c|c|c|c|c|c|c|c|c|c|c|}
\hline & 횽 & ' & $\sim$ & ' & $\stackrel{\infty}{\sim}$ & ' & $\sim$ & & $\stackrel{d}{N}$ & 1 & N & ' & $\stackrel{R}{1}$ \\
\hline & 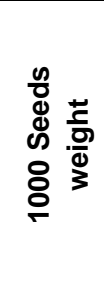 & 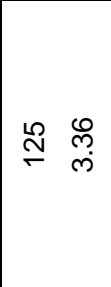 & ' & ' & 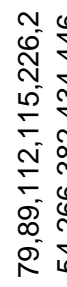 & 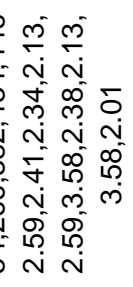 & & & 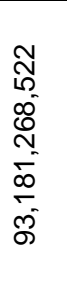 & 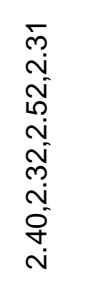 & $\stackrel{\text { మ్ల }}{\leftarrow}$ & $\underset{N}{N}$ & $\underline{0}$ \\
\hline & 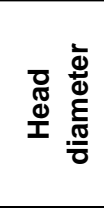 & 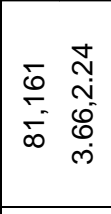 & ' & ' & $\begin{array}{l}\stackrel{p}{m} \\
\stackrel{m}{m}\end{array}$ & $\begin{array}{l}\stackrel{g}{+} \\
\stackrel{N}{+} \\
\stackrel{+}{+} \\
\stackrel{N}{i n}\end{array}$ & ' & & 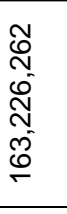 & $\begin{array}{l}\bar{c} \\
\bar{N} \\
\tilde{N} \\
\dot{v} \\
\dot{0} \\
\dot{m} \\
\dot{m}\end{array}$ & 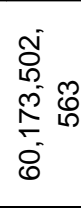 & 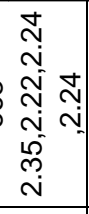 & $\mp$ \\
\hline & 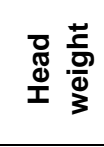 & ' & : & ' & ' & ' & ' & & & , & $\begin{array}{l}0 \\
0 \\
0 \\
0 \\
\end{array}$ & 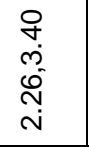 & $\sim$ \\
\hline 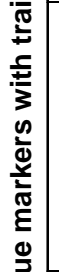 & 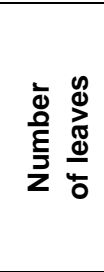 & $\bar{\infty} \stackrel{\substack{\infty \\
\stackrel{\infty}{N}}}{ }$ & 응 & 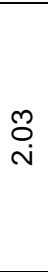 & $\stackrel{\stackrel{m}{ }}{\Gamma}$ & 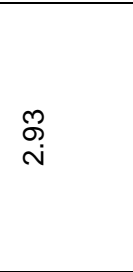 & ' & ' & 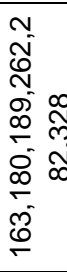 & 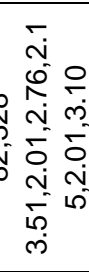 & 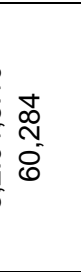 & 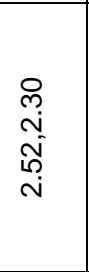 & $\mp$ \\
\hline 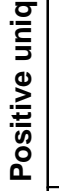 & 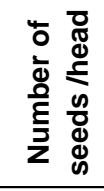 & ' ' ' & ' & ' & ' & ' & $œ$ & 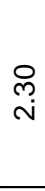 & $\begin{array}{l}\tilde{m} \\
\tilde{m} \\
\tilde{N}\end{array}$ & 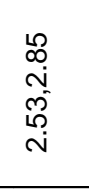 & $\stackrel{\mathfrak{n}}{\wedge}$ & 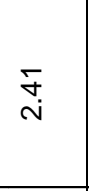 & $\nabla$ \\
\hline & 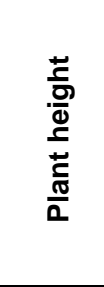 & & ' & ' & $\begin{array}{l}\hat{0} \\
\frac{0}{0} \\
\stackrel{0}{0} \\
0 \\
\overline{0} \\
\tilde{n}\end{array}$ & 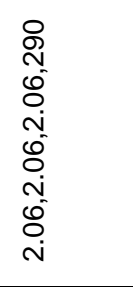 & $\stackrel{\infty}{\wedge}$ & $\stackrel{\leftrightarrow}{\stackrel{\sim}{*}}$ & 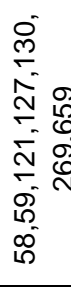 & 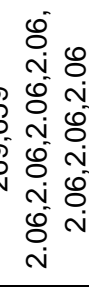 & 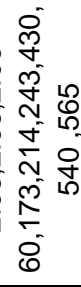 & 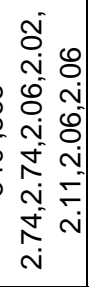 & 임 \\
\hline & 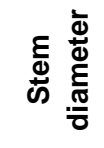 & $\bar{\varphi} \stackrel{\circ}{\circ}$ & $\stackrel{\mathbb{Z}}{\mathbf{Z}}$ & ָָ & $\stackrel{\infty}{\stackrel{\infty}{c}}$ & $\stackrel{\widehat{m}}{\mathrm{j}}$ & ' & ' & 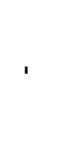 & ' & r. & 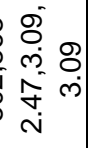 & 0 \\
\hline & 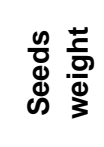 & ' ' & ' & ' & ' & ' & ' & , & 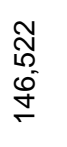 & $\begin{array}{l}\stackrel{\sim}{N} \\
\stackrel{N}{N} \\
\stackrel{N}{N}\end{array}$ & $\begin{array}{l}\cong \\
0 \\
\vdots \\
\\
\end{array}$ & $\begin{array}{l}\stackrel{8}{0} \\
\dot{m} \\
\infty \\
\stackrel{\infty}{+} \\
\text { Ǹ }\end{array}$ & $\nabla$ \\
\hline & ن. & 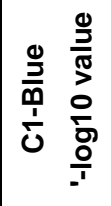 & 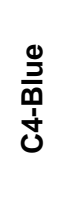 & $\begin{array}{l}\frac{0}{2} \\
\frac{2}{2} \\
0 \\
\frac{0}{0}\end{array}$ & 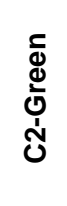 & $\begin{array}{l}\frac{0}{5} \\
\frac{5}{3} \\
0 \\
\frac{0}{0} \\
\frac{0}{1}\end{array}$ & 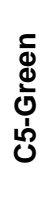 & $\begin{array}{l}\frac{0}{J} \\
\frac{\pi}{3} \\
0 \\
\frac{0}{0} \\
\frac{1}{2}\end{array}$ & $\begin{array}{l}\frac{3}{\bar{\delta}} \\
\frac{\delta}{\dot{\delta}}\end{array}$ & $\begin{array}{l}\frac{0}{5} \\
\frac{2}{0} \\
\frac{0}{8} \\
\frac{0}{11}\end{array}$ & $\begin{array}{l}\frac{3}{0} \\
\frac{0}{0} \\
\dot{0} \\
\dot{0}\end{array}$ & $\begin{array}{l}\frac{0}{50} \\
\frac{3}{0} \\
\frac{0}{8} \\
\frac{0}{1}\end{array}$ & $\begin{array}{l}\text { ㅍّㅁ } \\
\text { 은 }\end{array}$ \\
\hline
\end{tabular}


The highest number of positively associated markers traits were observed within four traits, le. plant height, 1000 seeds weight, head diameter and number of leaves being 19, 16, 11 and 11 positive unique marker, respectively. With respect to the lowest marker associated traits, head weight, number seeds per head and seed weight recorded the lowest value of positive unique marker: 2, 4 and 4 , respectively.

In this context, sampling strategies for yield components and morphological traits, along with marker trait association was analysed and exploitation in sunflower, by Luevanos- Escareño et al (2010) who estimated the hybridization between the cultivated sunflower Helianthus annuus and the wild species with ornamental potential Tithonia rotundifolia. The results of AFLP-based on DNA fingerprints were analyzed in a sample of ten familial trios, with an average of 28 polymorphisms per trio. The DNA fingerprinting analysis of the plants complemented the morphological study which allowed confirmation of the hybrid nature of the offspring. Moreno et al (2013) studied the genetic characterization of sunflower breeding resources in Argentina via marker trait association analysis for seed oil content. The results indicated that this information could take into account the diversity and selection of appropriate parental genotypes for successful hybridization. Purwati and Herwati (2016) analyzed marker-trait associations between TE-AFLP markers and oil content. The results showed that, two markers namely E_ac $\times$ P_a04 and $E \_$ac $x$ P_a39 were found to be associated oil content with high statistical significance $(P=$ 0.005). These results indicated that on the basis of their qualitative morphological traits, sunflower accessions possessed high diversity. The seed size and seed thickness showed significant positive correlation with 100 seeds weight. These two traits might be used as selection criteria in sunflower breeding programs for appropriate screening of parental genotypes included in hybridizing process aiming at the increase of plant productivity.

\section{CONCLUSION}

F-AFLP markers facilitate the simultaneous selection of several characters and can thus improve the efficacy of selection based on markers associated traits in the plant-breeding activities.

\section{REFERENCES}

Aboki M.A., Mohammed M., Musa S.H., Zuru B.S., Aliyu H.M., Gero M., Alibe I.M. and Inuwa B. 2012. Physicochemical and antimicrobial properties of Sunflower (Helianthus annuus L.) seed oil. Int. J. Sci. Tech., 2(4), 151-154.

Black W.C. ,Baer C.F., Antolin M.F. and DuTeau N.M. 2001. Population genomics: genome-wide sampling of insect populations. Annual Review of Entomology, 46, 441-469.

Bonin A., Ehrich D. and Manel S. 2007. Statistical analysis of amplified fragment length polymorphism data: A toolbox for molecular ecologists and evolutionists. Mol. Ecol., 16(18), 3737-3758.

Bukhsh M.A.H.A., Iqbal J., Kaleem S., Wasaya A. and Ishaque M. 2011. Qualitative analysis of spring planted sunflower hybrids as influenced by varying nutritional area. Pakistan J. of Nutrition, 10(3), 291-295.

Chambó E.D., Escocard de Oliveira N.T., Garcia R.C., Ruvolo-Takasusuki M.C.C. and de Toledo V.D.A.A. 2017. Phenotypic correlation and path analysis in sunflower genotypes and pollination influence on estimates. Open Biological Sci. J., 3(3), 9-15.

Duncan D.B. 1955. Multiple ranges and multiple $F$ test. Biometrics, 11(1), 1-42.

El-Wakil D.A. 2014. Seed-Borne Fungi of Sunflower (Helianthus annuus L.) and their Impact on Oil Quality. IOSR J. of Agric. and Veterinary Sci., 6(6), 38-44.

Gonthier L., Blassiau C., Mörchen M., Cadalen T., Poiret M., Hendriks T. and Quillet M.C. 2013. High-density genetic maps for loci involved in nuclear male sterility (NMS1) and sporophytic self-incompatibility (S-locus) in chicory (Cichorium intybus L., Asteraceae). Theor Appl Genet 126(8), 2103-2121.

Kandil A.A., Sharief A.E. and Amira A.M. 2016. Seedling parameters of some sunflower cultivars as affected by seed priming and salinity stress. Int. J. Agro. Agri. R. 9(2), 117-136.

Luevanos-Escareño, M.P., Reyes-Valdes M.H., Villarreal-Quintanilla J.A. and Rodriguez $\mathbf{R}$. 2010. Obtención de híbridos intergenéricos $\mathrm{He}$ lianthus annuus $\times$ Tithonia rotundifolia y su análisis morfológico y molecular. Acta Botánica Mexicana. 90, 105-118. 
Luikart G., England P.R., Tallmon D., Jordan S. and Taberlet P. 2003. The power and promise of population genomics: from genotyping to genome typing. Nature Reviews Genetics, 4, 981-994.

Magdy M., Werner O., McDaniel S.F., Goffinet B. and Ros R.M. 2016. Genomic scanning using AFLP to detect loci under selection in the moss Funaria hygrometrica along a climate gradient in the Sierra Nevada Mountains, Spain. Plant Biology, 18(2), 280-288.

Mahmoud A. and Abdel-Fatah B.E. 2012. Analysis of Genetic Diversity among Sunflower Genotypes using Agro-morphological Traits and Molecular Markers. Australian J. of Basic and Applied Sci., 6(13) 419-432.

Moreno M.V., Nishinakamasu V., Loray M.A., Alvarez D., Gieco J., Vicario A. and Lia V.V. 2013. Genetic characterization of sunflower breeding resources from Argentina: assessing diversity in key open-pollinated and composite populations. Plant Genetic Resources, 11(3), 238-249.

Purwati R. and Herwati A. 2016. Evaluation of quantitative and qualitative morphological characters of sunflower (Helianthus annuus L.) germplasm. Bio Diversitas 17(2), 462-465.
Razzaq H., Tahir H.N. and Sadaqat A. 2014. Genetic variability in sunflower (Helianthus annuus L.) for achene yield and morphological characters. Inter. J. Sci. Nat, 5(4), 669-676.

Reif J.C., Zhao Y., Würschum T., Gowda M., and Hahn V. 2013. Genomic prediction of sunflower hybrid performance. Plant Breeding, 132(1), 107-114.

Riaz A., Tahir M., Rizwan M., Nazir M.F. and Riaz B. 2017. Combining Ability Analysis for Achene Yield and Related Components in Sunflower (Helianthus annuus L.). Helia, 40(67), 177-188.

Storz J.F. 2005. Using genome scans of DNA polymorphism to infer adaptive population divergence. Molecular Ecology, 14, 671-688.

Suresha P.G., Kulkarni V.V., Supriya S.M., Darshan S. and Patil C.B. 2017. Genetic Diversity Analysis in Sunflower (Helianthus annuus L.) parental Lines Using SSR and RAPD Markers. Int. J. Curr. Microbiol. App. Sci., 6(7), 20692076.

Vos P., Hogers R., Bleeker M., Reijans M., van de Lee T., Hornes M., Friters A., Pot J., Paleman J., Kuiper M. and Zabeau M. 1995 .AFLP: a new technique for DNA fingerprinting. Nucleic Acids Research, 23, 4407-4414.

Zhang, Z., van Parijs, F.R.D. and Xiao, B. 2014. The status of AFLP in the genomics era and a pipeline. Mol Breeding, 34, 1245-1260. 
مجلة اتحاد الجامعات العربية للعلوم الزراعية ، جامعة عين شمس ، القاهرة ، مصر

مجلا(26)، عدد(2D)، عداند خاص ، 2501-2489، 2018

Website: http://strategy-plan.asu.edu.eg/AUJASCl/

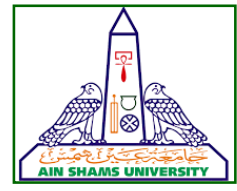

2501

المسح الجينومى بأستخدام فلوروسنت AFLP اريعة عشر تركيب وراثى لزهرة الثمس

[183]

$$
\begin{aligned}
& \text { مختار سعيد رزق1،1"-- فتحى محمد عبد التواب1 - أحمد أبو دومة } 1 \text { - }
\end{aligned}
$$

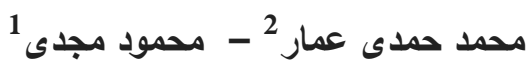

$$
\begin{aligned}
& \text { 1- قسم الوراثة - كلية الزراعة- جامعة عين شمس - ص.ب. } 68 \text { - حدائق شبرا } 11241 \text { - القاهرة - مصر } \\
& \text { 2- قسم الاصول الوراثية - مركز بحوث الصحراء - ص.ب. } 1 \text { شارع متحف المطرية 11753- المطرية - القاهرة - }
\end{aligned}
$$

*Corresponding author: drmokhtarsaid@yahoo.com

Received 6 June, 2018

Accepted 2 July, 2018

وجود ارتباط إيجابي عالي بين معظم الصفات. وقد

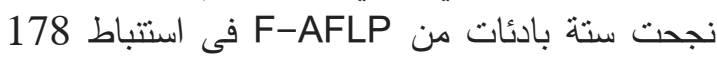

من الواسمات الجزيئية من اجمالى 1007 حزمة

متعددة الاشكال المظهرية بنسبة مئوية 97.42٪.

بالنسبة للواسمات الجزيئية المرنبطة بالصفات، لوحنة

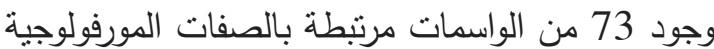

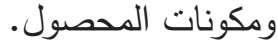

الكلمات الدالة:: زهرة الثمس، فلوروسنت AFLP،

الواسمات المساعدة لاتتخاب الصفات

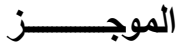

ينتمى زهرة الثمس الى العائلة النجمية. استخدمت

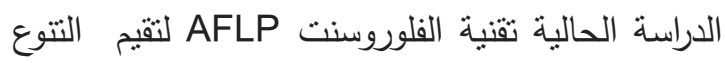
الوراثي لاربعة عثر تركيبا وراثيًا من عباد الثندس متضمنادراسة ثمانية صفات مورفولوجية واخرى مرتبطة بالصفات المحصولية. اظهرت النتائج اختلافات عالية التراتية

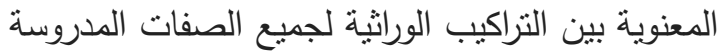

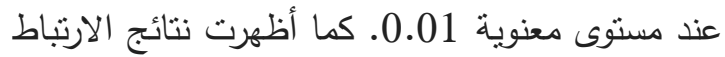
بين الصفات المدروسة عند مستوى معنوية 0.05 
